\title{
Penerapan Token Economy untuk Meningkatkan Perilaku Prososial Anak Usia Dini
}

\author{
Elizabeth Prima ${ }^{\bowtie}$, Putu Indah Lestari ${ }^{2}$ \\ Pendidikan Guru Pendidikan Anak Usia Dini, Universitas Dhyana Pura \\ DOI: $\underline{10.31004 / \text { obsesi.v4i1.324 }}$
}

\begin{abstract}
Abstrak
Penelitian ini bertujuan untuk meningkatkan perilaku prososial anak usia dini melalui penerapan Token Economy. Perilaku prososial adalah aspek perkembangan moral yang mencakup perilaku seperti empati, kedermawanan, kerjasama, peduli, dan banyak lagi. Penelitian ini telah dilaksanakan pada anak kelompok A Taman Kanak-kanak Denpasar pada Tahun Ajaran 2018/2019. Jenis penelitian ini adalah Penelitian Tindakan Kelas dengan menggunakan metode observasi. Subjek penelitian tindakan kelas ini adalah anak kelompok A berjumlah 17 anak. Objek penelitian ini adalah penerapan Token Economy untuk meningkatkan perilaku prososial anak usia dini. Hasil yang peroleh pada Siklus I menunjukkan 47,06\% telah mencapai ketuntasan, sedangkan pada Siklus II menunjukkan $82,35 \%$ yang mencapai ketuntasan. Dari Siklus I ke Siklus II terdapat peningkatan perilaku prososial sebesar 35,29\% dengan penerapan Token Economy Hal ini menunjukkan penerapan Token Economy dapat meningkatkan perilaku prososial anak usia dini.
\end{abstract}

Kata Kunci: token economy; perilaku prososial; anak usia dini

\begin{abstract}
Application of Tokens Economic to Improve Prosocial Behavior of Early Childhood's. This study aims to improve prosocial behavior of early childhood through the application of Tokens Economy. Prosocial behavior is an aspect of moral development that includes behaviors such as empathy, generosity, cooperation, caring, and more. This research was conducted in group A of Denpasar Kindergarten in 2018/2019 Academic Year. This type of research is Classroom Action Research using observation methods. The subjects of this classroom action research were group A children totaling 17 children. The object of this research is the application of Tokens Economy to improve prosocial behavior of early childhood. The results obtained in First Cycle showed that $47.06 \%$ had reached completion, while in second cycle $82.35 \%$ achieved completion. The results obtained in First to Second Cycle there was an increase in prosocial behavior by $35.29 \%$ with the application of Tokens Economy. This shows that the application of Tokens Economy can improve the prosocial behavior of early childhood.
\end{abstract}

Keywords: token economy; prosocial; early childhood.

Copyright (c) 2019 Elizabeth Prima, Putu Indah Lestari

$\triangle$ Corresponding author:

Email Address : elizabethprima@undhirabali.ac.id (Denpasar, Bali)

Received 11 November 2019, Accepted 24 November 2019, Published 25 November 2019 


\section{PENDAHULUAN}

Perilaku prososial pelan-pelan mulai luntur dari masyarakat Indonesia seiring perkembangan zaman yang semakin modern. Hal ini ditandai dengan adanya sikap individual di lingkungan sekitar, dimana minimnya keterlibatan anak dengan teman seumuran atau sebaya yang menyebabkan hilangnya kesempatan untuk bersosialisasi. Namun, perkembangan sosialisasi anak usia dini pada dasarnya sudah terjadi dengan adanya interaksi sosial terhadap lingkungan sekitarnya. Saat berinteraksi sosial, anak-anak diharapkan mampu menunjukkan perilaku prososial. guru yang memegang peranan penting di dalam kelas harus dapat mengajarkan kepada anak untuk dapat berperilaku prosossial dengan orang lain. (Mustika Sari, Toha, \& Nurani, 2018)Schroeder et al dalam (Gross, 2013) mendefinisikan bahwa, "Perilaku prososial mencakup perilaku yang dimaksudkan untuk menguntungkan orang lain, seperti menolong, menenangkan, berbagi, bekerja sama, menentramkan, membela, beramal, dan menunjukkan kepedulian."

(Beaty, 2014) berpendapat bahwa kerja sama mencakup berbagai perilaku prososial, termasuk bergiliran; bergantian menggunakan mainan, peralatan, atau kegiatan; memenuhi permintaan; mengkoordinasi tindakan-tindakan untuk mencapai tujuan; menerima ide-ide orang lain, dan bernegosiasi serta berkompromi dalam bermain. Lebih lanjut (Wentzel, 2015) menyatakan bahwa perilaku prososial berupa perilaku berbagi, bekerjasama, dan saling menolong.

Berbagi merupakan salah satu keterampilan prososial yang penting bagi anak usia dini karena perilaku ini paling sering terjadi di ruang kelas usia dini. Hal ini dapat dimengerti mengingat banyak kesempatan yang dimiliki anak-anak dalam satu kelompok untuk belajar berbagi satu sama lain. Berbagi ditandai dengan anak memberikan miliknya kepada orang lain (Beaty, 2014).

(Mercer, J. \& Clayton, 2012) berpendapat bahwa, “Perilaku menolong merupakan tingkah laku yang tidak mementingkan diri sendiri dan dimotivasi oleh keinginan untuk bermanfaat bagi orang lain." Sejalan dengan hal itu (Beaty, 2014) berpendapat bahwa, "Perilaku menolong terdiri dari memberikan kasih sayang, perhatian positif, penguatan atau perlindungan". Anak-anak bisa mempelajari perilaku menolong ketika guru memulainya dengan sebuah pembiasaan yang dilakukan didalam kelas.

Berdasarkan hasil observasi dan wawancara yang dilakukan kepada pihak sekolah, perilaku prososial anak tampak kurang maksimal. Hal ini ditandai dengan kurang maksimalnya anak dalam menunjukkan kepedulian kepada sesamanya. Terlihat masih banyak anak yang "cuek" untuk sebuah keberhasilan yang dicapai oleh temannya. Selain itu dalam hal menolong teman, sebagian anak masih enggan memberikan bantuan kepada teman yang lain ketika mereka sudah dapat menyelesaikan tugasnya dengan cepat. Anak lebih cenderung kurang peduli terhadap teman yang lain.

Salah satu strategi yang dipilih untuk mengembangkan perilaku prososial dalam penelitian ini adalah dengan menggunakan teknik Token Economy.

Token Economy merupakan suatu wujud modifikasi perilaku yang dirancang untuk meningkatkan perilaku yang diinginkan dan mengurangi perilaku yang tidak diinginkan dengan pemakaian token (tanda-tanda misalnya, kepingan koin atau stiker). Menurut Walker, et.al dalam (Hadi, 2005), tabungan kepingan adalah suatu teknik untuk pengukuhan tingkah laku yang ditujukan kepada seseorang anak yang sesuai dengan target yang telah disepakati, dengan menggunakan reward berupa hadiah untuk penguatan secara simbolik. Beberapa jenis kepingan (token) sebagai simbol pengukuhan yang sering digunakan anatara lain bintang emas, kertas kupon, sepotong kecil kertas warna, uang logam, stiker, perangko, kancing plastik dan sebagainya. Prosedur tabungan kepingan tidak berbeda dengan orang bekerja yang menerima upah berupa uang langsung setelah satu porsi pekerjaannya selesai. Program kepingan dapat diterapkan pada anak-anak normal, pada anak-anak atau orangorang yang perkembangannya terlambat, yang cacat mental, atau yang mengalami penyimpangan kepribadian. 
Oleh karena itu, dalam pelaksanaannya diharapkan anak dapat menerima token dengan cepat setelah menunjukkan perilaku yang diinginkan. Token itu dikumpulkan dan dapat dipertukarkan dengan suatu obyek atau kehormatan yang penuh arti (Davidson, 2010). Pada prinsipnya penghargaan mendorong anak untuk berprestasi. Peneliti akan menggunakan hadiah sebagai penguatan ekstrinsik dalam peningkatan perilaku prososial anak usia dini. Hal ini didukung pula dengan pendapat Tarbox, Ghezzi, Wilson dalam (Nurmawati, 2013) yang menyatakan bahwa Token Economy merupakan salah satu contoh dari perkuatan ekstrinsik yang menjadikan seseorang melakukan sesuatu untuk diraihnya yakni dapat meningkatkan perhatiannya baik dari tingkat intensitas maupun dari tingkat validitas. Tujuannya adalah mengubah motivasi yang ekstrinsik menjadi motivasi yang instrinsik, dengan cara ini diharapkan bahwa perolehan tingkah laku yang diinginkan dapat menjadi ganjaran untuk memelihara tingkah laku yang baru.

TK Angel Hearts Denpasar merupakan sekolah swasta yang berada di Denpasar Selatan yang berdiri sejak tahun 2018. Pada Tahun Ajaran 2018-2019 terdapat 17 siswa untuk kelas kelompok A. TK Angel Hearts dalam proses pembelajarannya belum menerapkan model Token Economy. Model pembelajaran yang digunakan di TK Angel Hearts masih bersifat klasikal dengan metode ceramah dan pemberian tugas. Permasalahan yang ditemukan pada saat melakukan observasi di Kelompok A dengan jumlah 17 anak, yaitu 10 anak perempuan dan 7 anak laki-laki adalah $64,70 \%$ anak masih terlihat rendah perilaku prososialnya. Selama melakukan pengamatan terhadap perilaku prososial anak, masih banyak anak yang kurang menunjukkan kemampuannya dalam bersosial.

Penelitian yang dilakukan oleh (Matondang, 2016) menyatakan berbagai upaya untuk membangun perilaku prososial telah dilakukan di Taman Kanak-kanak yang kelas manajemennya menggunakan pengelompokan multiage. Perilaku prososial pada anak-anak meliputi bentuk perilaku kooperatif, persahabatan, membantu, berbagi, dan peduli. Anakanak yang berperilaku prososial harus praktis terus menempatkan di lingkungan mereka sehingga dengan mudah anak dapat menyesuaikan diri dengan lingkungan sekolah, terutama sekolah di mana manajemen kelas menggunakan pengelompokan multiage. Berdasarkan hasil observasi, anak Kelompok A TK Angel Hearts Denpasar baru memiliki satu kelompok belajar, sehingga tidak memungkinkan untuk meningkatkan perilaku prososial melalui metode pengelompokan multiage, maka penelitian ini menggunakan metode Token Economy.

Penelitian ini bertujuan untuk mengetahui peningkatan perilaku prososial anak usia dini melalui penerapan Token Economy. Hal ini didukung penelitian (Sholihah, Hafidah, \& Syamsuddin, 2016) yang menunjukkan bahwa terdapat pengaruh penggunaan teknik Token Economy terhadap perilaku prososial anak usia dini. Penelitian ini merupakan penelitian tindakan kelas melalui 2 siklus dengan menggunakan metode observasi dan wawancara. Penerapan Token Economy ini diharapkan dapat meningkatkan perilaku prososial anak usia dini sehingga menjadi referensi bagi guru dalam pembiasaan yang dapat dilakukan dikelas.

\section{METODOLOGI}

Penelitian ini menggunakan desain penelitian tindakan kelas (classroom action research) yang secara umum bertujuan untuk meningkatkan perilaku prososial anak usia dini. Penelitian ini akan dilaksanakan dalam dua siklus dimana masing-masing siklus terdiri dari empat tahapan yaitu: perencanaan tindakan, pelaksanaan tindakan, observasi/evaluasi, dan refleksi.

Subjek penelitian ini adalah anak kelompok A TK Angel Hearts Denpasar, yang berjumlah 17 anak (terdiri dari 10 anak perempuan dan 7 anak laki-laki). Objek penelitian tindakan kelas ini dilakukan terhadap subjek penelitian di tingkat pendidikan Taman Kanak-kanak yaitu Penerapan Token Economy untuk meningkatkan perilaku prososial anak usia dini. 
Metode pengumpulan data yang digunakan dalam penelitian ini yakni melalui observasi, anecdotal records, dan dokumentasi. Data-data tersebut diperoleh melalui observasi dengan panduan rubrik untuk merekam data mengenai perilaku prososial yang ditunjukkan anak usia dini. Observasi yang dilakukan peneliti yaitu observasi terstruktur dan observasi tidak terstruktur. Proses observasi pemahaman perilaku prososial anak terstruktur dibantu dengan instrumen berupa angket observasi dengan indikator penelitian yaitu: menaati aturan yang berlaku dalam suatu permainan, menghargai orang lain, dan menunjukkan rasa empati. Sedangkan dalam melaksanakan observasi tidak terstruktur, pengobservasi tidak menyediakan daftar terlebih dahulu tentang aspek-aspek yang akan diobservasi. Dalam hal ini, observer mencatat semua tingkah laku yang dianggap penting dalam suatu periode observasi.

\section{HASIL DAN PEMBAHASAN}

\section{Hasil Siklus I}

Siklus I dengan tema Tanah Air diikuti sub tema Pulau Bali, Rumah Adat Bali, Tempat Wisata di Bali, dan Pakaian Adat Bali direncanakan untuk 4 kali pertemuan, masingmasing pertemuan dilaksanakan berdasarkan skenario pembelajaran. Proses penelitian ini menggunakan metode observasi pada setiap pertemuannya untuk menilai perilaku prososial anak. Secara rinci nilai rata-rata perilaku prososial anak dalam mengikuti kegiatan pembelajaran dengan menerapkan teknik Token Economy pada Siklus I dituangkan dalam Tabel 1 di bawah ini.

Tabel 1. Deskripsi Data Hasil Penelitian Siklus I

\begin{tabular}{|c|c|}
\hline & Perilaku Prososial Anak \\
\hline Valid & 17 \\
\hline Mean & 6.17 \\
\hline Median & 6,25 \\
\hline Modus & 6.67 \\
\hline Std Deviasi & 4,93 \\
\hline Minimum & 4 \\
\hline Maksimum & 10 \\
\hline
\end{tabular}

Skor hasil pengukuran responden diperoleh skor tertinggi adalah 10 dari skor tertinggi yang mungkin dicapai yaitu 12. Skor terendah responden adalah 4 dari skor terendah yang mungkin dicapai yaitu 4 .

Hasil observasi perilaku prososial anak akan dikonversikan dengan menggunakan pedoman konversi Penilaian Acuan Patokan (PAP) skala lima. Hasil capaian perilaku prososial anak pada Siklus I dapat dilihat pada tabel berikut:

Tabel 2 Hasil Capaian Perilaku Prososial Anak Siklus I

\begin{tabular}{|c|c|c|c|c|c|}
\hline No & $\begin{array}{l}\text { Persentase } \\
\text { Penguasaan }\end{array}$ & Jumlah & Persentase & Keterangan & Ketuntasan \\
\hline 1 & $0-54$ & 4 & 23,53 & $\begin{array}{l}\text { Sangat } \\
\text { Rendah }\end{array}$ & Belum \\
\hline 2 & $55-64$ & 5 & 29,41 & Rendah & \\
\hline 3 & $65-79$ & 7 & 41,18 & Sedang & \\
\hline 4 & $80-89$ & 1 & 5,88 & Tinggi & Tuntas \\
\hline 5 & $90-100$ & 0 & 0 & $\begin{array}{l}\text { Sangat } \\
\text { Tinggi }\end{array}$ & I untas \\
\hline
\end{tabular}

Dari Tabel 2 di atas, dapat diamati bahwa dari 17 anak, 4 anak (23,53\%) mendapat kategori sangat rendah, 5 anak $(29,41 \%)$ mencapai kategori rendah, 7 anak $(41,18 \%)$ mendapat katagori sedang, dan 1 anak (5,88\%) capaian perilaku prososialnya ada pada 
kategori tinggi. Namun belum ditemukan anak yang mencapai perilaku prososial kategori sangat tinggi. Dari 17 anak, terlihat 8 anak $(47,06 \%)$ sudah mencapai ketuntasan dalam perilaku prososial, sedangkan 9 anak $(52,94 \%)$ belum mencapai ketuntasan dalam perilaku prososial. Untuk lebih jelasnya dapat digambarkan pada grafik poligon di bawah ini:

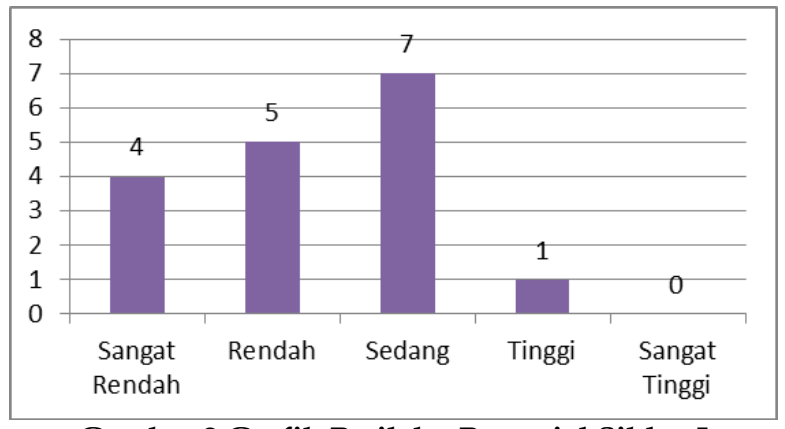

Gambar 2 Grafik Perilaku Prososial Siklus I

Hasil pemantauan seperti yang dipaparkan di atas menunjukkan bahwa secara umum tingkat perilaku prososial anak TK Angel Hearts Denpasar telah mencapai rata-rata keberhasilan dengan kategori sedang. Sehingga pada akhir Siklus I telah tercapai ketuntasan perilaku prososial yakni $47,06 \%$. Itu artinya hasil perilaku prososial anak di Siklus I belum mencapai ketuntasan minimal yaitu $80 \%$ sehingga penelitian akan dilanjutkan pada Siklus II.

\section{Siklus II}

Pelaksanaan tindakan Siklus II tidak jauh berbeda dengan pelaksanaan di Siklus I. Rencana Program Pembelajaran Mingguan (RPPM), Rencana Program Pembelajaran Harian $(\mathrm{RPPH})$, dan skenario pembelajaran dirancang dan disusun sesuai dengan tema yang digunakan di TK Angel Hearts Denpasar. Siklus II dengan tema Negaraku dan sub tema Lambang Negara Indonesia, Bendera Indonesia, Presiden dan Wakil Presiden Indonesia, dan Ibukota Indonesia direncanakan untuk 4 kali pertemuan, masing-masing pertemuan dilaksanakan berdasarkan skenario pembelajaran. Secara rinci nilai rata-rata perilaku prososial anak selama mengikuti kegiatan pembelajaran melalui teknik Token Economy pada Siklus II dituangkan dalam Tabel 3 di bawah ini.

Tabel 3 Deskripsi Data Hasil Penelitian Siklus II

\begin{tabular}{cc}
\hline & $\begin{array}{c}\text { Perilaku } \\
\text { Prososial Anak }\end{array}$ \\
\hline $\mathrm{N}$ & 17 \\
Valid & \\
\hline Mean & 8,02 \\
Median & 8,13 \\
Modus & 8,96 \\
Std Deviasi & 5,92 \\
Minimum & 6 \\
Maksimum & 12 \\
\hline
\end{tabular}

Skor hasil pengukuran responden diperoleh skor tertinggi adalah 12 dari skor tertinggi yang mungkin dicapai yaitu 12. Skor terendah responden adalah 6 dari skor terendah yang mungkin dicapai yaitu 4 .

Hasil observasi perilaku prososial anak akan dikonversikan dengan menggunakan pedoman konversi Penilaian Acuan Patokan (PAP) skala lima. Hasil capaian perilaku prososial anak pada Siklus II dapat dilihat pada tabel berikut: 
Tabel 4 Hasil Capaian Perilaku Prososial Anak Siklus II

\begin{tabular}{llllll}
\hline No & $\begin{array}{l}\text { Persentase } \\
\text { Penguasaan }\end{array}$ & Jumlah & Persentase & Keterangan & Ketuntasan \\
\hline 1 & $0-54$ & 0 & 0 & Sangat Rendah & Belum \\
2 & $55-64$ & 3 & 17,65 & Rendah & Tuntas \\
3 & $65-79$ & 4 & 23,53 & Sedang & \\
4 & $80-89$ & 7 & 41,17 & Tinggi & Tuntas \\
5 & $90-100$ & 3 & 17,65 & Sangat Tinggi & \\
\hline
\end{tabular}

Dari Tabel 4 dapat diamati bahwa terdapat 17 anak, tidak seorangpun anak mendapat kategori sangat rendah. Ada 3 anak (17,65\%) mendapat kategori rendah, 4 anak $(23,53 \%)$ mencapai kategori sedang, 7 anak $(41,17 \%)$ mencapai katagori tinggi dan sebanyak 3 anak (17,65\%) dengan kategori capaian sangat tinggi. Dari 17 anak, 14 anak (82,35\%) sudah mencapai ketuntasan perilaku prososial, sedangkan masih ada 3 anak $(17,65 \%)$ yang belum mencapai ketuntasan perilaku prososial. Untuk lebih jelasnya dapat digambarkan pada grafik poligon di bawah ini:

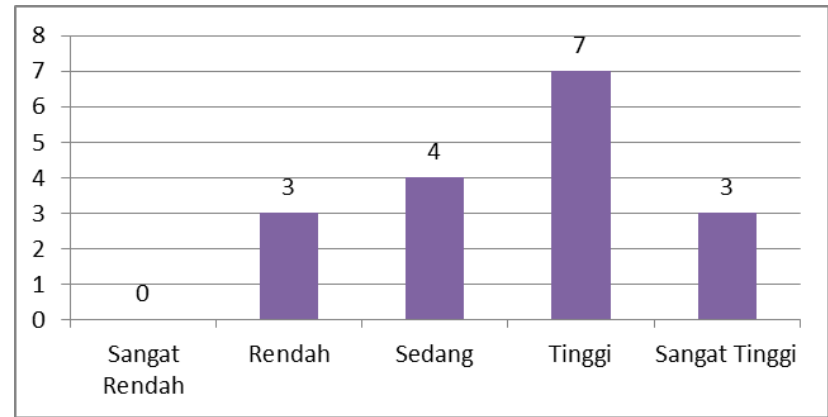

Gambar 4. Grafik Perilaku Prososial Siklus II

Hasil pemantauan seperti yang dipaparkan di atas menunjukkan bahwa secara umum perilaku prososial anak di TK Angel Hearts Denpasar telah mencapai rata-rata keberhasilan dengan kategori sedang, tinggi, dan sangat tinggi. Hal ini berarti bahwa penerapan teknik Token Economy mampu meningkatkan perilaku prososial anak karena pada akhir Siklus II telah mencapai ketuntasan yakni $82,35 \%$ dengan sebagian besar anak memperoleh kategori tinggi dan sangat tinggi. Hasil perilaku prososial anak di Siklus II telah mencapai ketuntasan minimal yaitu $80 \%$ sehingga penelitian dihentikan sampai tahap ini.

\section{PEMBAHASAN}

Temuan empiris yang diperoleh peneliti di lapangan terhadap perilaku prososial anak Kelompok A TK Angel Hearts Denpasar pada Siklus I menunjukkan bahwa dari 17 anak, 8 anak $(47,06 \%)$ sudah mencapai ketuntasan perilaku prososial sedangkan 9 anak $(52,94 \%)$ belum mencapai ketuntasan perilaku prososial.

Beberapa anak mengalami kesulitan pada indikator memperlihatkan perilaku menghargai keunggulan orang lain. Pada Siklus I, masih banyak anak yang belum memperlihatkan perilaku menghargai keunggulan dengan cara yang sederhana yaitu memuji temannya. Hal yang terjadi di dalam kelas adalah ketika anak-anak dapat menyelesaikan pekerjaannya atau melakukan sesuatu yang hebat, teman yang lain hanya diam saja. Anak-anak terkesan biasa saja dengan pancapaian yang diperoleh temannya. Oleh karena itu diterapkanlah teknik Token Economy. Beberapa hal yang melandasi bahwa penggunaan teknik Token Economy berpengaruh terhadap perilaku prososial anak, yaitu teknik ini memainkan peranan penting dalam membantu untuk memodifikasi perilaku 
tertentu. Hal ini senada dengan yang nyatakan oleh (Zlomke, K., \&Zlomke, 2003), bahwa Token Economy dapat digunakan untuk mengurangi atau memperkuat perilaku tertentu.

Aspek positif dari Token Economy adalah memperkuat perilaku yang tepat dan mencegah perilaku yang tidak sesuai, sehingga meminimalkan kebutuhan untuk menggunakan strategi dalam menangani perilaku yang tidak sesuai. Token economy dilaksanakan dengan cara memberikan token kepada anak yang berperilaku prososial. McLaughin dan William dalam (Doll, McLaughlin, \& Barreto, 2013) berpendapat bahwa jenis token dapat berupa chip, tiket, koin, uang palsu, kelereng, stiker, dan perangko. Token yang digunakan dalam penelitian ini berbentuk koin yang akan dimasukkan kedalam celengan. Pada penelitian ini, peneliti ingin memunculkan perilaku prososial dengan menggunakan teknik Token Economy. Menurut Kazdin, Token Economy digunakan sebagai sarana untuk mengelola perilaku siswa (Doll et al., 2013).

Pada penelitian ini, indikator yang cukup baik dikuasai oleh anak-anak adalah menaati peraturan yang berlaku dalam suatu permainan. Anak-anak terlihat tidak canggung dalam menunjukkan ketertibannya saat bermain dan mengikuti instruksi yang diberikan oleh guru. Anak sangat berdisiplin mematuhi peraturan yang diberikan oleh gurunya, sehingga tidak terlalu sulit untuk mengatur anak-anak dalam melakukan sebuah permainan. Tetapi mereka masih perlu dituntun saat berkerjasama dalam kelompok agar permainan dapat berjalan dengan baik. Anak masih terlihat canggung dalam berkerjasama satu dengan yang lain dalam sebuah tim atau kelompok. Oleh karena itu Token Economy digunakan dalam penelitian ini untuk memberikan penguatan agar anak mampu bersikap kooperatif atau bekerjasama dalam segala hal yang dilakukan secara berkelompok. Setiap kali anak mampu bekerjasama dengan mengikuti instruksi yang diberikan oleh peneliti, maka anak akan mendapatkan koin untuk segera dicelengkan kedalam celengannya masing-masing.

Pada tahap awal anak masih malu-malu dan cenderung bermain secara individu meskipun kegiatan yang diberikan dalam bentuk kelompok. Setelah adanya pemberian token pada pelaksanaan maka nampak anak mulai belajar untuk bekerja sama, berbagi dan menolong. Greenberg dan Tomasello dalam (Paulus. et al., 2014) menyatakan bahwa anak usia prasekolah biasanya berbagi setelah bekerjasama dengan orang lain. Berbagi dan bekerja sama merupakan keterampilan prososial yang penting di pusat prasekolah karena perilaku ini paling sering terjadi di ruang kelas anak usia dini. Hal ini dapat dimengerti mengingat banyak kesempatan yang dimiliki anak-anak dalam satu kelompok untuk belajar berbagi material satu sama lain dan juga bekerjasama.

Temuan empiris pada Siklus II untuk perilaku prososial, secara umum tingkat perkembangan prososial anak Kelompok A TK Angel Hearts Denpasar telah mencapai ratarata keberhasilan dengan kategori sedang, tinggi, dan sangat tinggi. Hal ini menyatakan bahwa penerapan teknik Token Economy mampu meningkatkan perilaku prososial anak karena pada akhir Siklus II telah tercapai ketuntasan yakni $82,35 \%$ dengan sebagian besar anak memperoleh kategori tinggi dan sangat tinggi. Senada dengan hal ini, penelitian yang telah dilakukan Prima \& Lestari, (2018) dengan jenis penelitian tindakan kelas yang berjudul, "Penerapan Teknik Token Economy Untuk Meningkatkan Kedisiplinan Anak Usia Dini" menunjukkan bahwa terjadi peningkatan kedisiplinan dengan penerapan teknik Token Economy. Pada Siklus I kedisiplinan sebesar 65,38 \% yang berada pada kategori sedang mengalami peningkatan pada Siklus II menjadi 92,31 \% yang tergolong pada kategori tinggi.

Hasil dari perilaku prososial anak dari tahap observasi sampai Siklus II telah terjadi peningkatan. Ketuntasan perilaku prososial di tahap observasi sebesar 35,30\%, Siklus I sebesar 47,06\%, dan ketutasan perilaku prososial di Siklus II sebesar 82,35\%. Perilaku prososial anak Kelompok A TK Angel Hearts meningkatan sebesar 47,05\% dari observasi awal hingga ke Siklus II telah mencapai ketuntasan minimal yaitu 80\%. Setiap aspek dalam perilaku prososial anak pada Siklus II juga mengalami peningkatan dibandingkan dengan Siklus I. Hasil peningkatan perilaku prososial dapat dilihat pada Gambar 5 di bawah ini. 


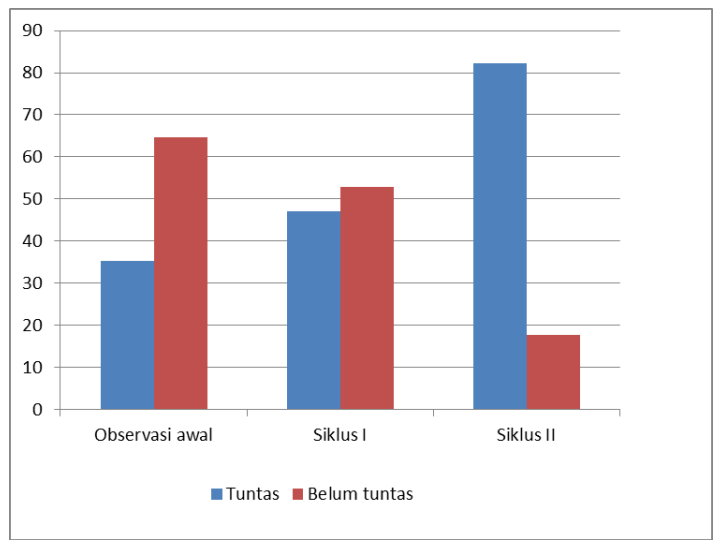

Gambar 5. Grafik Hasil Peningkatan Perilaku Prososial Anak Usia Dini

Salah satu kesimpulan dalam penelitian ini yaitu adanya peningkatan perilaku prososial pada anak Kelompok A TK Angel Hearts Denpasar melalui teknik Token Economy setelah dilakukan sebanyak 2 siklus. Hal ini dikarenakan anak kelompok A termotivasi dengan adanya hadiah atau reward dari token yang dikumpulkan setiap harinya. Token Economy memiliki kecenderungan untuk meningkatkan motivasi intrinsik anak untuk termotivasi dalam meningkatkan perilaku prososial. Hal ini sesuai dengan pendapat (Corey, 2013) bahwa Token Economy dapat digunakan untuk membentuk tingkah laku apabila persetujuan dan pemerkuat-pemerkuat yang tidak bisa diraba lainnya tidak memberikan pengaruh.

\section{SIMPULAN}

Hasil penelitian dan pembahasan menunjukkan bahwa Token Economy dapat diterapkan bagi anak usia dini. Jenis token yang dipergunakan dalam penelitian ini adalah koin yang ditabungkan dalam celengan masing-masing anak. Berdasarkan uraian diatas dapat disimpulkan bahwa implementasi teknik Token Economy dalam penelitian ini dapat meningkatkan perilaku prososial anak usia dini di Kelompok A TK Angel Hearts Denpasar dengan capaian kriteria ketuntasan minimal yaitu 14 anak (82,35\%) dengan kategori sedang, tinggi, dan sangat tinggi.

\section{UCAPAN TERIMAKASIH}

Peneliti mengucapkan terima kasih kepada Rektor Universitas Dhyana Pura yang telah memberikan hibah penelitian dasar. Ketua dan staf LPPM yang telah memfasilitasi penelitian ini, Ketua Program Studi PG-PAUD Universitas Dhyana Pura, dan TK Angel Hearts Denpasar yang telah memberikan kesempatan kepada peneliti untuk dapat meneliti di sekolah. Peneliti juga mengucapkan terima kasih kepada dewan redaksi jurnal Obsesi yang memberi kesempatan kepada peneliti untuk berbagi ilmu, sehingga hasil penelitian ini menjadi berkah untuk kemajuan ilmu pendidikan anak usia dini.

\section{DAFTAR PUSTAKA}

Beaty, J. J. (2014). Observasi Perkembangan Anak Usia Dini. In Prenada Media.

Corey, G. (2013). Teori Praktek Konseling dan Psikoterapi. Bandung: Refika Aditama.

Davidson, G. (2010). Psikologi Abnormal. Jakarta: Rajawali Press.

Doll, C., McLaughlin, F. T., \& Barreto, A. (2013). The Token Economy: A Recent Review and Evaluation. International Journal of Basic and Applied Science, 2(01), 131-149.

Gross, R. (2013). Psychology: The Science of Mind and Behaviour (Sixth Edition). In Pustaka Pelajar.

Hadi, P. (2005). Modifikasi Perilaku. In Departemen Pendidikan Nasional.

Matondang, E. S. (2016). Perilaku Prososial (Prosocial Behavior) Anak Usia Dini Dan 
DOI: 10.31004/obsesi.v4i1.324

Pengelolaan Kelas Melalui Pengelompokan Usia Rangkap (Multiage Grouping). EduHumaniora: Jurnal Pendidikan Dasar, 8(1). https:// doi.org/10.17509/eh.v8i1.5120 Mercer, J. \& Clayton, D. (2012). Psikologi Sosial. In Erlangga.

Mustika Sari, I. T., Toha, H., \& Nurani, Y. (2018). Improving Early Childhood Prosocial Behavior through Activity Storytelling with Puppets. Jurnal Obsesi : Jurnal Pendidikan Anak Usia Dini, 2(2), 155. https:/ / doi.org/10.31004/obsesi.v2i2.75

Nurmawati, E. I. (2013). Penerapan Metode Modifikasi Perilaku Token Economy untuk Mengurangi Conduct Disorder. Procedia Studi Kasus Dan Intervensi Psikologi, 1(1).

Paulus., M., Licata, M., Kristen, S., Thoermer, C., Woodward, A., \& Sodian, B. (2014). Social Understanding and Self-Regulation Predict Pre-Schoolers Sharing with Friends and Disliked Peers: A Longitudinal Study. International Journal of Behavioral Development, 1(12). https:/ / doi.org/10.1177/0165025414537923

Prima, E., \& Lestari, P. I. (2018). The Improvement of The Discipline for Early Childhood Through Token Economy Technique. Jurnal Obsesi : Jurnal Pendidikan Anak Usia Dini, 2(2), 245. https:// doi.org/10.31004/obsesi.v2i2.124

Sholihah, M., Hafidah, R., \& Syamsuddin, M. M. (2016). Pengaruh Teknik Token Economy Terhadap Perilaku Prososial Anak Usia 4-5 Tahun. 4(3).

Wentzel, K. (2015). Prosocial Behaviour and Schooling. Encyclopedia on Early Childhood Development. In University of Maryland at College Park.

Zlomke, K., \&Zlomke, L. (2003). Token Economy Plus Self -Monitoring to Reduce Disruptive Classroom Behaviors. Behavior Analyst Today, 4(2), 177-182. https:// doi.org/10.1037/h0100117 